\title{
Alice no País da Especulação Imobiliária Habitação e Modos de Vida na Cidade de São Paulo
}

Marcelo Tramontano *

\begin{abstract}
$\mathrm{R}$ habitar da cidade de São Paulo, Brasil, comparando-os às transformações percebidas nos modos de vida e no perfil demográfico da população. Esse assunto faz parte das preocupações do Nomads.usp Núcleo de Estudos sobre habitação e Modos de Vida, da Universidade de São Paulo, coordenado pelo autor, que procura repensar o desenho dos espaços da habitação contemporânea, considerando as transformações ocorridas nos grupos familiares a partir da revolução industrial inglesa, suas atuais tendências comportamentais, assim como sua relação com o uso de novas mídias. Isto inclui o redesenho de seu mobiliário e a revisão de seu repertório construtivo, priorizando preocupações de cunho ambiental, através de reflexões teóricas e da realização de projectos arquitectónicos experimentais.
\end{abstract}

Palavras-Chave: habitação; modos de vida; São Paulo; Brasil.

Brasil, primeiras décadas do século XIX. Sozinha no planalto, separada do porto de Santos e das novidades do mundo pela densa mata tropical da Serra de Paranapiacaba que cobre um desnível de oitocentos metros de altura, está edificada a pequena São Paulo de Piratininga, com uma população que não chega a vinte mil almas. Suas ruas poeirentas, suas casas térreas com beiral largo, construídas em taipa de pilão de maneira simplória, conferem-lhe um perfil completamente distinto daquele da capital do Império: embelezado por missões de artistas e arquitectos franceses, o Rio de Janeiro abriga duzentas mil pessoas já em 1840, e é, em 1860, a maior cidade latino-americana, com seus quatrocentos mil habitantes. A vila de Piratininga situa-se sobre o topo praticamente plano de uma pequena colina, de onde domina a paisagem calma um longo edifício de taipa de pilão, iniciado no distante ano de 1554 por missionários jesuítas que aí abrigaram um colégio. É onde está a sede do governo provincial, e é, nestes campos pouco habitados, a primeira construção de feições europeias de que se tem notícia. Caminhos para o mar e para o interior partem do centro da aglomeração urbana, que estrutura-se sobre um triângulo formado por três ruas principais, por onde passam carregadores de água, tropeiros, escravos. Às mulheres só é permitido deixar o interior sombrio e despojado das casas se acompanhando seus maridos, ou, se forem meninas, seus pais. Os escravos, que, oficialmente, não são uma classe social, mas propriedades, parecem chegar a um terço da população, se tanto. Os prestadores de serviço são identificados por Nestor Goulart Reis Filho como "um verdadeiro exército de aguadeiros, como de lavadeiras, que retiravam as roupas de cada domicílio e lavavam junto aos rios e ribeirões. (...) Mas também (...) os que transportavam alimentos para a cidade, os vendedores ambulantes, os responsáveis pelo transporte de objectos pesados e cargas, os que fabricavam embalagens como barris, potes de cerâmica e peças de madeira, os índios ou mestiços que caçavam e pescavam, os remadores, os carregadores e sobretudo os que cuidavam das tropas de muares e asseguravam a circulação de mercadorias" (Reis Filho, 1994:17). A austeridade e o comportamento arredio dessa população fazem parte de um mesmo perfil em que se inserem a vida simples, os hábitos moralistas, a moradia despojada.

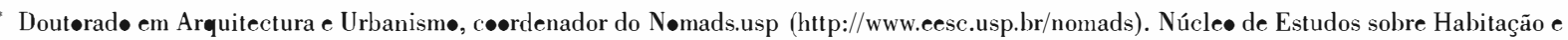
Modos de Vida, da Universidade de São Paulo, Brasil. Contacto: tramont@sc.usp.br
} 


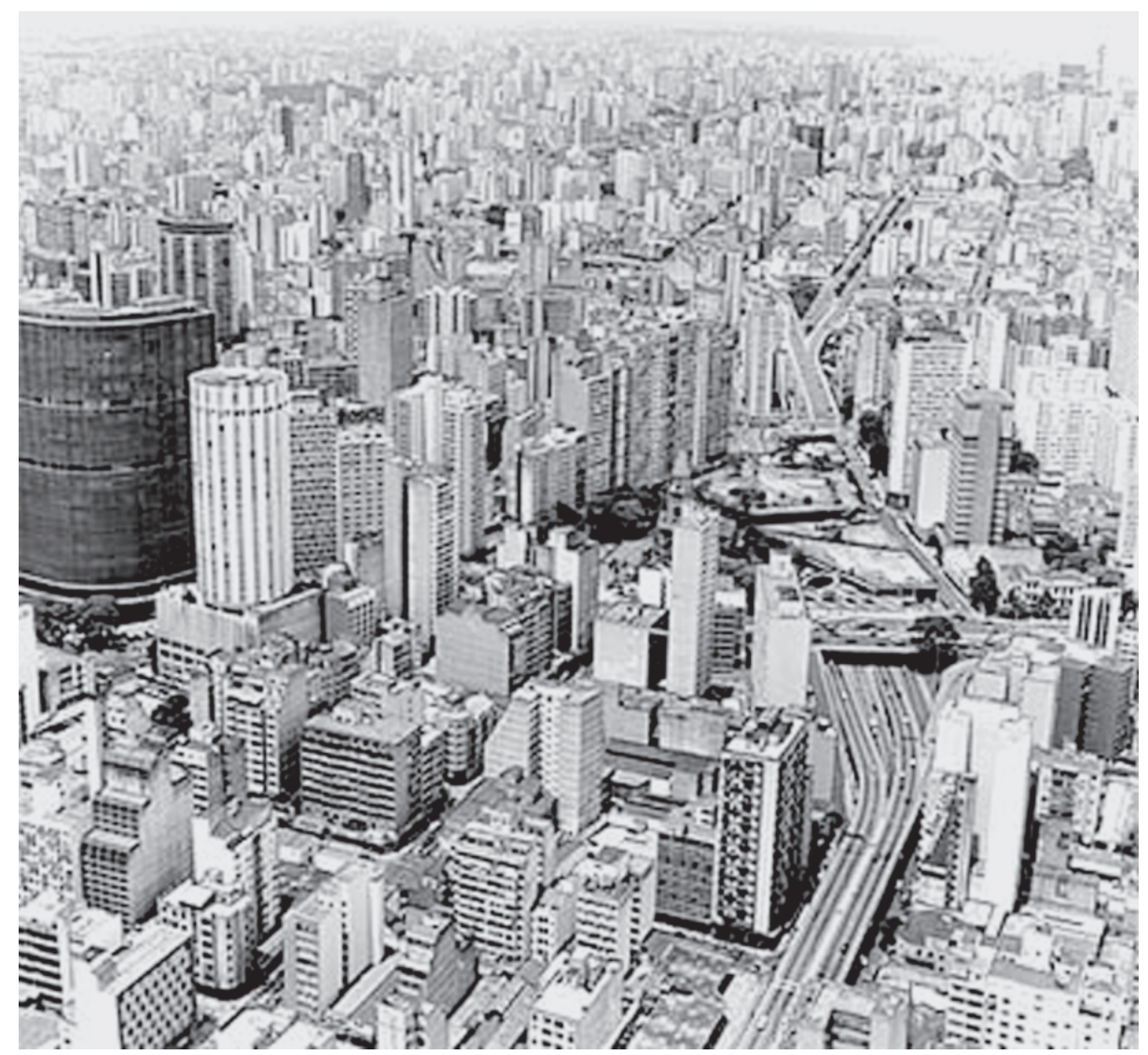

Foto de Nelson Kon / São Paulo, 2002.

A casa urbana típica espelha as rígidas fronteiras sociais entre a instância pública e o universo privado: térrea, com paredes externas de taipa de pilão e divisórias internas de taipa de mão, um corredor central ligando a rua ao espaço de convívio do grupo familiar, a varanda ${ }^{1}$, nos fundos. Situadas de ambos os lados deste eixo, duas salas de visitas voltam-se para a rua, e para elas se abrem as alcovas reservadas aos viajantes de passagem, dando as costas às alcovas dos membros da família que se abrem, por sua vez, para a varanda. O estranho é mantido à distância, ainda que bem-vindo. Um puxado lateral nos fundos, distante da rua e dos olhos de estranhos, abriga a cozinha e os demais espaços de serviço. Mas não é raro que a comida seja preparada ao ar livre, no quintal, em meio à fumaça do fogo a lenha, à moda das mulheres indígenas. A casa se protege sob uma grande cobertura de telhas tipo canal dividida em duas águas, que se unem em uma cumeeira paralela à rua. Como nas cidades portuguesas, as casas tocam-se lateralmente: janelas, só as das salas, voltadas para a rua, e as da varanda, abertas para o quintal. Uns poucos sobrados abrigam as famílias mais abastadas, expressando diferenças de status social no cenário urbano, ainda que construídos, em geral, com os mesmos materiais empregados nas casas mais pobres. Mobiliário e equipamentos são também semelhantes, fabricados, muitas vezes, pelos próprios moradores ou por seus serviçais.

A crer nos relatos encontrados na literatura, a privacidade intra-grupo era pouco conhecida por esta sociedade que ainda vivia segundo os costumes dos primeiros tempos da colónia, quando fazendas completamente isoladas da civilização, a muitas centenas de quilómetros dos núcleos urbanos importantes, abrigavam grupos domésticos que incluíam senhores, serviçais e escravos, frequentemente em relações de intimidade e, não raro, promíscuas $^{2}$. No interior da província, vastas

\footnotetext{
Diferentemente do sentido que damos hoje a esta palavra no Brasil, a varanda era um espaço confinado, situado nos fundos da casa urbana paulistana oitocentista, que ocupa toda a largura do lote urbano, e onde a família costuma reunir-se "em torno da grande mesa de refeições, espreguiçar-se nas redes rangedoras, ao lado de gaiolas de pássaros, do alto relógio de pêndulo e de vasos de plantas", segundo descreve o professor Carlos Lemos (Lemos, 1985: 52).

2 Sobre esse assunto, ver o excelente estudo feito por Leila Algranti (1997).
} 
plantações de café, cuidadas por mão-de-obra escrava, sustentavam a hegemonia de uma elite rural ainda tacanha e dispersa em um território grande demais, prestes, no entanto, a desempenhar um dos papéis principais no processo de modernização da capital. Isso porque é para facilitar o acesso dos grãos ao porto marítimo, até então transportados em lombo de burro serra abaixo, que serão inauguradas, na década de 1870, as primeiras ferrovias, entre elas a San Paulo Railway, ligando Jundiaí e São Paulo ao porto de Santos. A partir de então, a pequena cidade do planalto será o destino preferencial de um número crescente de pessoas até tornar-se, pouco mais de um século mais tarde, a terceira mais populosa aglomeração urbana do planeta.

\section{Ricos, Pobres e as Ideias Modernas}

Diferentemente da Europa e do Extremo Oriente, o território brasileiro não foi palco das horríveis batalhas da Segunda Guerra Mundial. Além das já conhecidas implicações nos planos humano, económico, político, etc., isso significou, por um lado, que a arquitectura brasileira não se veria confrontada aos grandes esforços de reconstrução que, naqueles países, ajudaram a disseminar a habitação modernista. Tampouco conheceria a involuntária tabula rasa que o conflito produziu em outras paragens, quer fossem reconstrução e tabula rasa - um problema sério ou a sorte grande dos arquitectos locais. Da segunda, a arquitectura brasileira conhecerá uma face menos destruidora com a construção de Brasília: em pleno cerrado, iniciada a partir do traçado de uma cruz, em um "gesto primário de quem assinala um lugar" no meio do nada, como teria dito o arquitecto Lucio Costa, autor do seu Plano Piloto. Mas verá uma tabula rasa a conta-gotas ir depredando todas as demais cidades do país, através de um trabalho contínuo e sistemático de especuladores imobiliários que reconstruirão, sim, muitas e muitas vezes, as cidades sobre o entulho da demolição delas próprias. Por outro lado, anunciada pela ditadura populista de Getúlio Vargas como um inevitável efeito da Guerra, a Lei do Inquilinato, de 1942, congelou aluguéis durante mais de duas décadas e afugentou o capital privado do até então fértil terreno dos investimentos no sector da construção de habitações para aluguel. Junte-se a isso a escassez de materiais durante os anos em que durou o conflito, com a consequente diminuição no ritmo de produção de novas unidades, e os preços altíssimos dos aluguéis de imóveis novos, não abrangidos pela lei varguista. Pronto. Estes fatos bastaram para transformar a questão da habitação na cidade de São Paulo, sobretudo aquela destinada aos mais pobres, em um pesadelo do qual os paulistanos nunca mais despertariam.

Por volta do final da Guerra, o rápido aumento do número de pessoas a alojar ${ }^{3}$ é motivado tanto por um crescimento industrial que atrai, como sempre, mão-de-obra de comunidades menores e da zona rural, quanto pelos despejos que se fizeram comuns, por aquela época, na cidade ${ }^{4}$. Sem outra escolha, uma parte crescente da população vai morar nas ruas, em áreas públicas vazias, onde constróem, a exemplo do Rio de Janeiro, o que passa a ser um território privilegiado da especulação imobiliária sobre as classes populares: favelas novas em folha. Da parte dos governos populistas da época, as respostas foram bem pouco contundentes, já que entre 1937 e 1964 foram produzidas apenas 142 mil unidades habitacionais em conjuntos ${ }^{5}$. As bases do desenho desta habitação alimentavam-se, em princípio, nas mesmas fontes modernistas que nutriram a reconstrução pós-guerra nos países sinistrados: blocos colectivos de apartamentos pequenos, destinados a famílias nucleares de trabalhadores, implantados em fileiras entre áreas ajardinadas, produzidos em série em um país cuja indústria da construção, no entanto, praticamente inexistia. Não é, com certeza, uma produção tão expressiva como a que se registrou na Alemanha do Bauhaus, na França ou no Japão. Essas habitações eram modernistas em sua estética, em sua intenção de "uma nova habitação para um novo homem", em sua proposta quase nunca posta em prática de serem produzidas industrialmente

\footnotetext{
3 A população paulistana passa de 1,3 milhões em 1940 para 2,2 milhões em 1950. (Dados dos Recenseamentos Gerais de 1940 e 1950 , IBGE) Entre 1940 e 1970, as taxas decenais de crescimento populacional chegam a ultrapassar 5\% ao ano. (Taschner, 1995: 509)

${ }^{4}$ Buscando actualizar os valores dos aluguéis, burlando, portanto, a lei, muitos proprietários acabavam despejando seus inquilinos sob pretextos vários, estes sim legais, ainda que falsos. Em seguida, reajustavam os aluguéis a preços exorbitantes, procurando repor as perdas causadas pelo congelamento prolongado, e prevenir-se contra eventuais novas leis restritivas.

5 Dados de Taschner (1998).
} 
e, muito raramente, na maneira de basear a elaboração de seu programa em dados sociológicos e demográficos. E só.

Não foi por falta de tentar. $\mathrm{O}$ arquitecto ítalo-brasileiro Rino Levi projectara, em 1944, o edifício Prudência, na elegante avenida Higienópolis, onde o conceito modernista de espaço doméstico flexível será desenvolvido de maneira inédita no país, buscando aproximar o agenciamento dos interiores às necessidades específicas de cada grupo familiar. A área de $400 \mathrm{~m}^{2}$ de cada apartamento é, praticamente, dividida em duas grandes zonas: em uma concentram-se os espaços húmidos e os quartos de empregada; a outra, pontuada pelos pilares de sustentação, destina-se aos espaços de convívio e aos quartos principais, delimitados por divisórias leves e armários. Apesar de apenas pouco mais da metade da área total da unidade é passível de ser re-arranjada, o uso de armários e de divisórias leves é inovador por permitir uma flexibilidade permanente no uso de alguns espaços.

Esta concepção espacial dos apartamentos chocava-se com certos consensos da elite brasileira da época. Um deles, que parece estar em vigência até hoje, era o de que a residência de prestígio devia caracterizar-se por uma sucessão de cómodos com finalidades específicas, o que excluía qualquer possibilidade de sobreposição de funções. Ou seja, mesmo o televisor, grande evento da habitação dos anos 1960, inicialmente situado na sala de estar, viu-se atribuir-se, mais tarde, uma sala de televisão, diferente das salas de jantar, de almoço, etc.. A inexistência desta estanqueidade na casa das classes populares - apesar de aparentemente buscada como símbolo de êxito social - associada ao fato de muitas delas lançarem mão de improvisações como divisórias feitas com tapumes, cortinas e armários, teriam veiculado, para o conjunto da sociedade, uma imagem de precariedade ligada à miséria material que as casas duráveis das pessoas com algum êxito social jamais deveriam expressar. Esta hipótese poderia contribuir para justificar o fato de que a totalidade dos apartamentos do edifício de Rino Levi teve suas vedações internas leves substituídas por paredes de tijolos nos anos posteriores à sua conclusão. Poderia, também, ajudar a explicar a resistência, por parte das classes abastadas, a morar em casas cujas salas de estar, de jantar, de televisão e a cozinha configurassem, por exemplo, um cômodo único. O professor Nestor Goulart Reis Filho lembra que a cozinha e as áreas de serviço seriam, sobretudo até 1945, "locais de completa desvalorização social, verdadeiro desprestígio, quase tabu herdado dos tempos em que ali estariam os escravos e, agora, acomodando os filhos daqueles." (Reis Filho, 1970:72) ${ }^{6}$

\section{O Afrancesamento se Americaniza}

$\mathrm{O}$ arquivista francês Yves Bruand, em seu incontornável Arquitetura Contemporânea no Brasil, dá uma visão bastante clara, ainda que bem resumida, de duas das principais modalidades habitacionais no país, nos anos finais da década de 1960 (Bruand, 1991:17). Ele menciona a residência particular de luxo, que mistura equipamentos típicos do então considerado conforto moderno com a presença de várias empregadas domésticas. Sua organização interna, no entanto, separa sistematicamente os espaços de serviços, voltados para os fundos do lote, dos espaços ditos sociais, voltados para a rua, seja qual for a orientação da casa. Resquícios da casa colonial paulistana? Talvez. Bruand sublinha que "é sempre total a independência entre as circulações social e de serviço". E que estes princípios também são encontrados nas residências destinadas à classe média e até mesmo nas casas populares. A segunda modalidade descrita no Arquitetura Contemporânea são os edifícios de apartamentos, construídos, na época, diz Bruand, única e exclusivamente pela iniciativa privada. Símbolo incontestável de modernidade e sucesso social, os apartamentos visavam abrigar as famílias mais ricas porque, ao que parece, seu custo era elevado; e seu custo era elevado porque visavam abrigar as famílias mais ricas. Faltava, isso sim, vontade política e interesse de investidores para produzir habitação colectiva verticalizada e económica, destinada às classes populares. No que concerne os interiores destes apartamentos caros, repetem-se os princípios de organização da casa isolada, fiel ao modelo da Belle Epoque francesa exportado para diversas partes do mundo: tripartição em zonas de prestígio (social),

\footnotetext{
${ }^{6} \mathrm{O}$ autor lembra ainda que "algumas senhoras mais ricas, podendo manter governanta, geralmente alemã ou francesa, lá não apareciam, quando muito deixando-se chegar à copa em busca de água."
} 
de recolhimento (íntima) e de rejeição (de serviços), estanqueidade funcional entre cômodos, entre áreas, entre circulações.

Nenhum trabalho sistemático e organizado, no campo da industrialização da habitação, de estatura equivalente aos estudos dos franceses Marcel Lods e Jean Prouvé, seria encontrado no país do concreto e da alvenaria de tijolos, neste momento. Os poucos paulistas que se aventuraram no terreno incerto da inovação técnica e arquitetónica parecem ter-se mirado mais em exemplos norte-americanos do que em experiências europeias. O que não é sem consequências para o projecto da habitação convencional. Que o digam os nomes dos cômodos da casa brasileira que, após terem sido traduzidos do francês para o português, são abandonados em prol de seus sinónimos em língua hollywoodiana: hall, living-room, closet... A evolução do desenho e da função dos cômodos também é dinâmica e revela diferenças locais. O cômodo parisiense chamado office, por exemplo, intermediário entre a cozinha e a salle à manger, vai perdendo o sentido conforme se acentua a ausência de pessoal doméstico nas residências, sobretudo após a Segunda Guerra Mundial. Na casa do francês comum, o espaço de sociabilidade, tanto para refeições familiares como para recepção de visitantes, passa a chamar-se salle à manger, alusão ao cômodo tipicamente burguês que a maioria nunca conheceu. Já em São Paulo, o office transforma-se, no decorrer do século Xx, em copa, azulejada como a cozinha, e passa a receber diversos móveis da sala de jantar até substituí-la completamente na maioria das habitações: o espaço de refeições é, agora, a copa, e somente os mais abastados dão-se ao luxo de dispor de uma sala de refeições. Ou de jantar, conforme a tradução do inglês dinning room. Em uma posterior redução de área, a copa brasileira se funde com a cozinha, e a consequente copa-cozinha, onde supostamente pode-se instalar a mesa de refeições, passa a ser o principal - mas não o mais prestigioso - espaço de sociabilidade da casa. Actualmente, nos pequenos e numerosos apartamentos da cidade, a copa desapareceu de vez. Reduzidos, seus armários revestem as paredes de uma cozinha igualmente diminuta, e a outrora central e generosa mesa de refeições é, com frequência, apenas uma prancha escamoteável aparafusada na parede, com alguns banquinhos empilháveis à sua volta. Refeições com amigos, só na mesa da sala, também pequena, ou pelo sistema dito americano: sem mesa. Por sua recorrência, a configuração resultante destes desenvolvimentos pode, sem dúvida, ser considerada uma tipologia, visto que disseminou-se por grande parte do país e definiu a organização do que hoje entendemos como a casa brasileira. $\mathrm{Ou}$, em todo caso, paulista.

\section{Menos Nascimentos e Vida Mais Longa}

Iniciado em fins da Idade Média europeia e estendendo-se por quatro séculos recheados de mudanças sociais, políticas e económicas profundas, o processo de nuclearização da unidade familiar vê-se sucedido pelo seu próprio estilhaçamento, potencializado, a partir do final dos anos 1960, quando começam a surgir, em diversas partes do mundo, novos formatos de grupos domésticos: famílias monoparentais, casais sem filhos, uniões livres - incluindo os já melhor aceitos casais homossexuais -, grupos coabitando sem laços conjugais ou de parentesco entre seus membros, e uma família nuclear renovada, ainda dominante nas estatísticas, mas com um enfraquecimento da autoridade dos pais em benefício de uma maior autonomia de cada um de seus membros. Todos passos em direcção a um novo padrão social: pessoas vivendo sós ${ }^{7}$. As causas desta evolução são inúmeras e, relativamente, recentes.

Um primeiro indicador das mudanças em curso são as flutuações da taxa de fecundidade. Na década de 1960, considerando-se o conjunto da população brasileira, esta taxa foi alta, de 5,8 filhos por mulher, caindo para 4,3 no período entre 1975 e 1980, com uma diminuição de 25,9\%. (Patarra, 1988). Os dados para 1990 apontam um declínio ainda mais marcante, atingindo o valor de 3,5 filhos por mulher, o que significa uma queda

Conforme Philippe Ariès, citado por R. Chartier (1991:409). Supomos que tal processo, iniciado na Idade Média com as separações preliminares entre, de um lado, membros da família do patrão e, de outro, empregados e aprendizes vivendo sob o mesmo teto, tenha atravessado o século XIX, reafirmando a opção burguesa de nuclearização da família, e estenda-se até os nossos dias, em direcção à individualização extrema: uma sociedade formada basicamente por singles vivendo sós. Não se trata, certamente, de uma evolução linear, regular e unívoca, mas, incontestavelmente longa e, aparentemente, irreversível. 
de quase $40 \%$ em apenas 20 anos. Ainda com grandes variações regionais - em 1990, a taxa nordestina é de 4,9 enquanto que, na região Sudeste, ela já se limita a 2,9 -, a grande variação percentual em todas as regiões faz crer que, a médio prazo, os padrões reprodutivos se homogenizem. No Estado de São Paulo, nota a professora Suzana Pasternak Taschner, o número médio de filhos por mulher em 1970 era de 4,0, caindo dez anos depois para 3,39, e atingindo 2,36 em 1993. (Taschner, 1997). A Contagem de População de Meio da Década, feita em 1995 pelo Instituto Brasileiro de Geografia e Estatística, também constatou este declínio. Segundo seus dados, a fecundidade foi de apenas 2,05 filhos por mulher nas áreas urbanas paulistas, ligeiramente acima do Rio de Janeiro, onde a taxa foi de apenas 1,9 (Taschner, 1998).

Longe de ser um fenómeno unicamente brasileiro, o turning point da fecundidade parece situar-se no ano de 1965, como apontam tanto os Censos e Pesquisas Nacionais por Amostras de Domicílios brasileiros, como levantamentos relativos a diversos países. É importante perceber que, por trás da queda da fecundidade, encontra-se uma mulher que reivindica, entre outras coisas, um lugar no mercado de trabalho, a liberdade de ter relações sexuais dissociadas da obrigatoriedade católica de procriação, o direito de escolher quando ter - ou não ter - filhos, o direito de separar-se do parceiro - ou parceira - sem ser, por isso, estigmatizada pela sociedade. Esta nova postura feminina, respaldada pela difusão de métodos contraceptivos mais acessíveis e mais eficazes, vai tornar-se passagem obrigatória de qualquer reflexão sobre as alterações nos padrões de comportamento herdados dos anos 1960. Como resume a demógrafa Elza Berquó, "a queda acentuada da fecundidade, o aumento da longevidade, a crescente inserção da mulher no mercado de trabalho, a liberação sexual, a fragilidade cada vez maior das uniões, o individualismo acentuado, etc., são tendências que vêm actuando no sentido de alterar o tamanho, a estrutura e a função da família." (Berquò, 1989).

Entre as principais razões para esta queda do número de filhos está a disseminação dos métodos contraceptivos que, somada à alta - embora, no caso brasileiro, dificilmente mensurável - incidência de aborto provocado, fortalece a reivindicação, sobretudo feminina, por uma maternidade voluntária à qual se segue a chamada liberação da mulher, fazendo com que a sexualidade se dissocie cada vez mais da procriação. Além disso, a escolarização cada vez mais extensa requisitada socialmente na preparação dos filhos, a integração

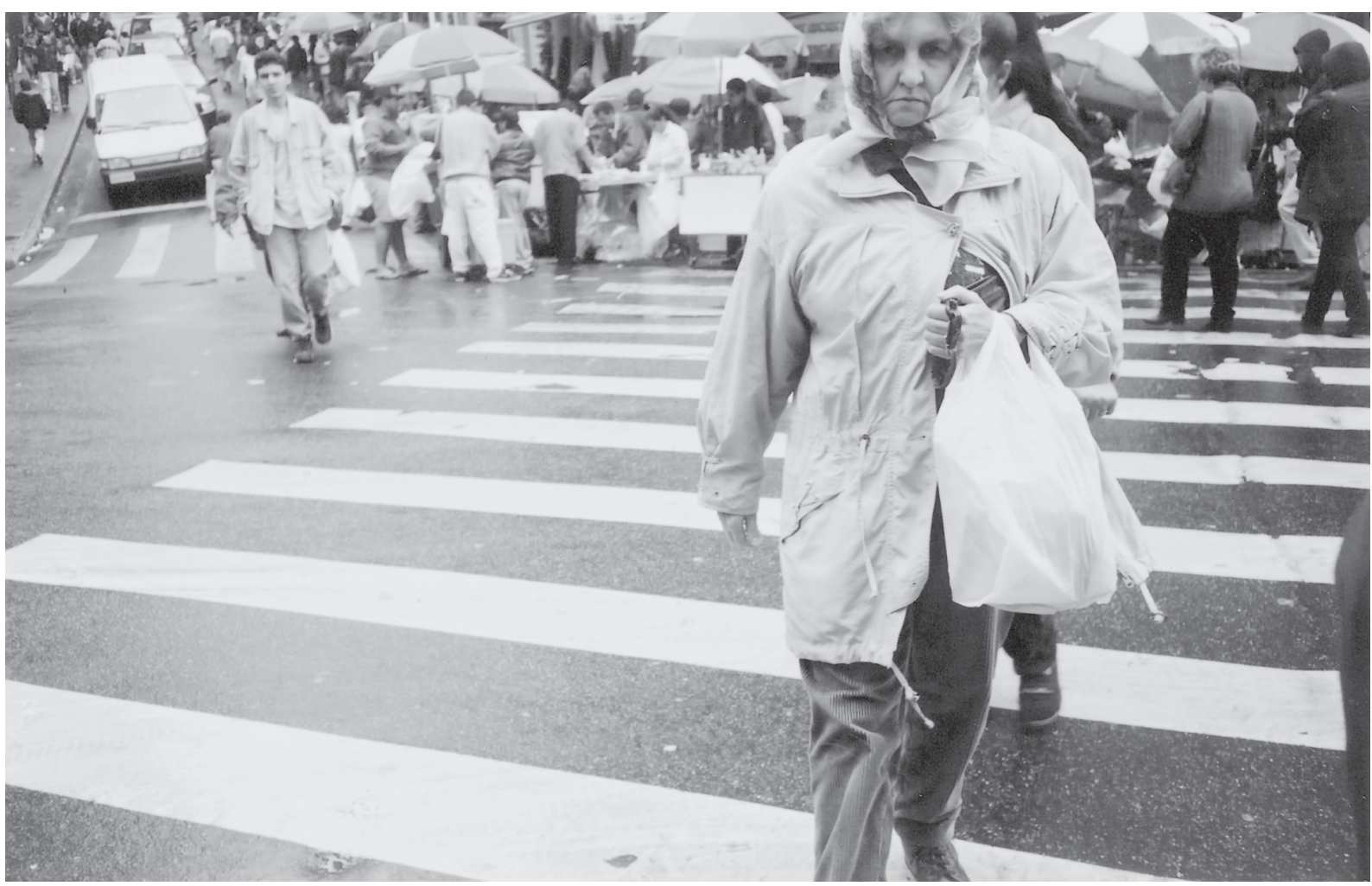

São Paulo, 2003 / Foto Marcelo Feijó. 
da mulher na divisão social do trabalho, a dissolução da família como unidade de produção, a crescente probabilidade da separação dos casais e as condições precárias de habitação nas grandes cidades desestimulam, sem dúvida, a geração de grande número de filhos. Todas estas mudanças se referem a diversas áreas do mundo, entre elas São Paulo, e acham-se estreitamente ligadas à vida urbana, o que explicaria por que as cidades estão sempre na vanguarda do movimento em direcção à queda da fecundidade, e deixaria supor que o papel dos meios de comunicação de massa está, também neste caso, longe de ser desprezível.

Por outro lado, os avanços tecnológicos, sobretudo na área das Ciências Médicas, e o grande aumento de domicílios alcançados pelas benfeitorias do saneamento básico tiveram como consequência, no Brasil, um rápido declínio da mortalidade - novamente, com fortes diferenças regionais -, iniciado já nos anos 1940 e acentuando-se a partir da década de 1950. Para se ter uma ideia, em 1980 morriam, no Brasil, 81,53 a cada mil meninos nascidos vivos durante o primeiro ano de vida, 51,21 no estado de São Paulo. Estes números caem, felizmente, chegando a 58,85 por mil em 1985, para todo o Brasil, e a 26,20 para o estado de São Paulo, em 1993 (Taschner, 1997). Aliado a uma fecundidade mais estável, este declínio gerou taxas de crescimento populacional relativamente altas, criando a imagem do que acabou conhecido como a explosão demográfica brasileira. $\mathrm{O}$ resultado foi a conformação de uma população jovem: durante as três décadas que separaram os anos 1940 dos anos 1970, mais da metade da população encontrava-se em idades inferiores a vinte anos, o que significou altas taxas anuais de inserção no mercado de trabalho e demandas sociais crescentes. No entanto, o início da rápida e acentuada queda da fecundidade, em meados dos anos 1960, vem transformar este quadro, reduzindo as taxas de crescimento populacional, é verdade, mas, sobretudo, contribuindo para a configuração de uma estrutura etária da população bem diferente da prevalecente nas décadas anteriores. Entre 1992 e 1996, a participação dos idosos de sessenta anos ou mais na população brasileira cresceu de $7,9 \%$ para $8,6 \%$, ao passo que a de crianças de menos de dez anos de idade caiu de $22,1 \%$ para $19,9 \%$. Na região Sudeste, que inclui o estado de São Paulo, praticamente um em cada dez habitantes tinha mais de sessenta anos em 1996. Já as crianças de menos de dez não passavam de $17,7 \%$ da população total ${ }^{8}$. O envelhecimento da população é claro, e suas principais causas são a queda da fecundidade e da mortalidade.

Se, por um lado, o número de nascimentos diminui e morrem menos recém-nascidos, por outro, as pessoas idosas vivem mais tempo. É o chamado aumento da esperança de vida ao nascer, cuja tendência crescente faz prever a consolidação do novo perfil etário da população. Em 1940, um brasileiro podia, ao nascer, esperar viver, em média, parcos 41,2 anos. Este número evolui para 53,7 na década de 1960, representando um ganho de doze anos e meio em um período de apenas três décadas. Em 1980, os brasileiros nascidos no estado de São Paulo já podiam entrever um futuro mais longo: 63 anos para os homens, e 70 para as mulheres. Por conta das ainda grandes diferenças regionais, a esperança de vida dos paulistas foi, em 1995, de 73 para as mulheres contra 65 anos para os homens, ao lado de uma média nacional, no mesmo ano, de 69 para mulheres e 63 para homens (SEADE, 2000).

\section{Menores e Diversos, os Novos Grupos Domésticos}

Redução da fecundidade e envelhecimento da população têm sido as causas directas da diminuição de tamanho do grupo familiar em todo o mundo ocidentalizado. A família brasileira, que se compunha por, em média, cinco pessoas em 1960, foi se reduzindo até atingir 4,34 em 1981, 4,2 em 1987, e 3,87 pessoas em 1990. Permaneceu, contudo, maior do que a família paulista média, que, em 1981, compunha-se de 3,98 pessoas e em 1995, de 3,69.

Paralelamente, uma tendência de relativização da importância do casamento vai favorecer o interesse dos jovens pelas chamadas uniões livres ou consensuais. Livre do controle do Estado, mas também de sua protecção, a participação deste formato familiar no conjunto de grupos brasileiros

\footnotetext{
${ }^{8}$ O percentual de idosos em 1996 foi de 9,3\%, segundo dados da PNAD - Pesquisa Nacional por Amostra de Domicílios. IBGE, 1996.

${ }^{9}$ Dados de IBGE (1995), Castelo Branco (1989) e Berquò (1998).
} 
foi ligeiramente crescente durante a década de 1960, e quase dobrou nos anos 1970. No Brasil, este tipo de arranjo familiar tem estado associado, historicamente, aos hábitos das classes mais pobres da população, ou constituiu-se na única alternativa de união conjugal para as pessoas separadas judicialmente antes da sanção do divórcio, em 1978. Apesar de a opção pelas uniões livres preceder um bom número de casamentos mundo afora, inclusive de brasileiros, ela se difunde sobretudo entre jovens de menos de vinte e cinco anos como parte de um novo modo de vida. O aumento do número de divórcios, a opção pelo celibato, o retardamento do primeiro casamento, o envelhecimento da população e consequente aumento do número de viúvos - ou viúvas, predominantemente -, o crescimento do número de mães solteiras, são algumas das determinantes tanto da diminuição do número de pessoas por grupo doméstico como pelo aumento do número de grupos. Destes divorciados, celibatários e viúvos, muitos têm optado por viver sozinhos.

Em todos os países ocidentalizados, morar só parece estar sendo a opção de uma parcela crescente da população. No que concerne o Brasil, apenas 5,9\% de todas as habitações do país eram ocupadas por uma única pessoa em 1981, contra 6,7\% em 1987. No estado de São Paulo, em 1994, os grupos domésticos compostos por uma única pessoa já perfazem 7,5\% do total de grupos: seriam $7,7 \%$, se considerada toda a região metropolitana, e 8,7\% para apenas a cidade de São Paulo (Seade, 1994). Esses números escondem formatos familiares distintos, e uma diversidade ainda maior de modos de vida. Em sua maioria, vivem sós jovens que apenas ingressaram no mercado de trabalho e que, seguindo uma tendência mais ampla, decidiram adiar a data do primeiro casamento. Cada vez mais, os jovens começam seu percurso no campo da habitação por uma vida solitária, o que não exclui fases de coabitação antes ou depois deste período, ou de coabitação parcial simultaneamente. Vivem sós também as pessoas saídas de uma relação conjugal que terminou em divórcio, em geral em torno dos 40 anos. E, ainda, vivem sós aqueles ou, na maioria das vezes, aquelas - que enviuvaram, após muitas décadas de união conjugal, caracterizando singles de terceira idade, com necessidades habitacionais bastante específicas. Estes solteiros, produtos da dissolução da família e do aumento da longevidade da população, tem tempo livre e, em geral, meios financeiros suficientes para realizar boa parte de suas expectativas materiais. Tempo livre e dinheiro não são, no entanto, suficientes para capacitar pessoas a encontrar sua identidade. Além do seu trabalho, estes indivíduos esperam fazer parte de redes de actividades sociais ou culturais, o que aumenta a demanda por lugares de uso público como quadras, ginásios esportivos e outros equipamentos sociais, assim como museus, bibliotecas, galerias e outros equipamentos culturais locais.

Corolário do aumento do número de pessoas vivendo sós, o crescimento recente do número de famílias monoparentais é atribuído, principalmente, aos divórcios e às rupturas de uniões livres. Em menor número, aos casos de viuvez, e ao crescente número de mães solteiras, que também pode estar reflectindo uma nova postura da mulher com relação à reprodução e à estrutura familiar. $\mathrm{Na}$ prática, a monoparentalidade significa grupos familiares chefiados predominantemente por mulheres - 89\% dos casos brasileiros, em 1995 (Berquò, 1998) - e pode ser apenas uma etapa transitória na vida de um grupo familiar, sucedendo uma separação conjugal, precedendo uma nova união. A participação das famílias monoparentais brasileiras no total de grupos domésticos vem aumentando nas últimas décadas. Em 1994, uma em cada dez famílias da região metropolitana de São Paulo é formada apenas pelo chefe e seus filhos. Somando-se aí a porcentagem dos grupos que reúnem um chefe, seus filhos e parentes, o número subiria para $14,7 \%$ do total dos grupos (SEADE, 1994).

No Brasil, esta configuração familiar é conhecida, já há algumas décadas, na forma de famílias com chefia feminina, com características bem particulares: são famílias no limiar da miséria, vivendo sobretudo em meio urbano, compostas pela mãe, filhos e, algumas vezes, parentes. O baixo nível de renda explica-se, em geral, pelo fato de os filhos serem ainda pequenos, e os eventuais parentes, velhos demais para trabalhar e contribuir no orçamento familiar. Vivem nas cidades por causa da maior possibilidade de trabalho para a mãe, e o pai ausente abandonou-os, ou morreu, ou nunca fez parte do grupo, ou procura trabalho em outra região. Este modelo, apesar de majoritário, vê emergir um outro, ligado aos novos padrões de comportamento, onde a mulher-chefe pertence às faixas mais altas de renda. Trata-se aí de mulheres 
profissionais das classes médias, que assumem a responsabilidade do trabalho remunerado na família porque são qualificadas para isso, detendo a guarda dos filhos após uma eventual separação conjugal. Os efeitos destas mudanças no campo da habitação são de diversas ordens. As separações multiplicam o número de grupos domésticos, diminuindo seu tamanho médio. $\mathrm{O}$ cônjuge que passa a morar só necessita de espaço para receber os filhos nos finais de semana ou até por mais tempo, no caso de opção pela guarda alternada. Os problemas de visita e guarda dos filhos, assim como a necessidade frequente da ajuda dos parentes, leva os divorciados e chefes de família monoparental a buscar a proximidade de seus domicílios, quase sempre em meio urbano. Além disso, processa-se uma alteração de papéis no seio destas famílias, devida, muitas vezes, à ausência do chefe por razões de trabalho, e ainda à provável queda do nível de vida após a separação, o que costuma levar ao ingresso de um ou mais filhos no mercado de trabalho.

Mesmo que novos formatos familiares aumentem cada vez mais sua participação no total de grupos, a grande maioria dos paulistas e paulistanos vive ainda o ciclo de vida nuclear, ao qual veio acrescentar-se, como se diz, a etapa do ninho vazio, quando os casais ficam sós após a partida dos filhos. No entanto, o modelo casal-com-filhos passa, em todos os países ocidentalizados, por dois tipos de diminuição: a do número de filhos, contribuindo para a redução do tamanho médio dos grupos familiares, e a de sua participação no total dos grupos domésticos. Neste segmento predominam os chamados casais DINKs, ou Double Income No Kids. Seu modo de vida baseia-se no desejo de levar uma vida confortável, garantida pela remuneração dos dois parceiros, mantendo a liberdade e a sensação de uma vida de solteiro, e pela possibilidade de melhor dispor do próprio tempo livre sem a necessidade de dividi-lo com obrigações domésticas decorrentes, em grande parte, da presença dos filhos. Contudo, interessa-nos aqui reunir algumas das principais características do grupo formado por pais e filhos que, apesar de historicamente majoritário, não deixou de sofrer profundas alterações em suas relações internas, frente às mudanças que afectaram estas sociedades nas últimas décadas. A redistribuição da autoridade constitui uma destas alterações, reforçada pelo aumento do número de mães trabalhando fora de casa, que põe em cheque a própria estrutura da família nuclear, baseada na tradicional divisão sexual do trabalho. Assim, constata Antoine Prost (1991), a família deixa de ser uma micro-sociedade. "Deixa de ser uma instituição para tornar-se um simples ponto de encontro de vidas privadas." A independência de seus membros aumentou, é verdade, o que se traduz pela afirmação do individualismo no conjunto da sociedade. De secundária, e, às vezes, até clandestina, a vida privada dos indivíduos dentro do núcleo familiar passou a ser, nas últimas décadas, reconhecida, respeitada e estimulada. Dos filhos, os pais já não exigem obediência cega mas êxito social e profissional.

Com a redução do número de filhos, o aumento de seu grau de independência com relação aos pais, e a diversificação das possibilidades de autonomia financeira da mãe, deixam de existir razões para que a família nuclear prolongue-se por toda a vida - cada vez mais longa, diga-se - de seus membros, continuando a existir após o fim do amor conjugal. Assim, tudo leva a crer que este formato familiar torne-se, cada vez mais, apenas um momento transitório - e não mais obrigatório - da trajectória individual de cada vez menos pessoas.

\section{As Décadas Perdidas}

Se, já nos anos 1960 e 1970, vários desses indicadores sociais e demográficos brasileiros e paulistanos acompanharam tendências internacionais, é bom notar que, no terreno do projecto da habitação, as principais problemáticas enfrentadas pelos seus arquitectos exibiram diferenças enormes. De seu lado, os países ricos descobriam as delícias do consumo, endinheirados que estavam em plenas Trente Glorieuses, que é como os franceses chamam os trinta anos ininterruptos de crescimento económico, inflação baixa e emprego para todos, a partir do término da Segunda Guerra Mundial, e que só terminaram mesmo depois dos dois grandes choques económicos que abalaram o mundo nos anos 1970, as crises petrolíferas de 1973 e 1979. Na segunda metade dos anos 1960, a Europa tinha as mais baixas taxas de desemprego de toda a história do trabalho assalariado - apenas 2,8\% de sua população economicamente activa. As estrondosas manifestações de 1968 nas ruas de Paris tinham como pano de fundo a garantia das 
liberdades individuais, o que ajudava a situar suas reivindicações no patamar dos sonhos realizáveis. Com a abundância, era mais fácil e mais adequado sonhar, e não precisava ser um sonho impossível sobre um lugar inexistente e feliz. Para a maioria, a utopia dos rebeldes estava aqui e agora, ao alcance da mão. Estudos como os de Archigram, dos Metabolistas japoneses, do CRAM e tantos outros, vinham permeados de um certo optimismo, de uma confiança no futuro que permitia pensar em megaestruturas caras erguendo-se na baía de Tokyo, por exemplo, e dedicavam-se a reflectir reflexão, aliás, totalmente legítima - sobre as possíveis relações entre cidade, imagem, consumo e arquitectura, sempre com a omnipresença do poderio industrial.

$\mathrm{O}$ arquitecto brasileiro, então com sua imprensa censurada, seus contactos com o exterior dificultados, debatia-se com problemas de outra ordem. Uma diferença de renda enorme e crescente entre ricos e pobres e entre o Norte e o Sul do país legava à cidade de São Paulo um saldo migratório positivo nunca visto antes. 'A cidade que mais cresce no mundo', na ufanista propaganda oficial, via sua população favelada de pouco mais de setenta mil pessoas, em 1973, já passar dos cento e dezassete mil, apenas dois anos depois, indo beirar os quatrocentos e quarenta mil em 1980 (Taschner, 1993). O próprio ano de 1968, que em tantas partes do mundo evoca ideias de libertação, ficaria para sempre marcado nos calendários brasileiros como o ano da violência chamada AI-5, o ato institucional que amordaçou a imprensa e intimidou políticos, sacramentando de vez o terror de Estado em nosso país. Ser arquitecto no Brasil, naqueles anos, pressupunha dedicar-se à busca de soluções para o monstruoso déficit habitacional, até como parte de uma atitude política contra o governo central. Isto se explica: a concepção arquitetónica das habitações de interesse social era praticamente a mesma em todo o país, com mínima variação local. Assim, aos arquitectos de empresas públicas, cabia quase unicamente a elaboração de planos urbanísticos, distribuindo as casinhas ou os predinhos nas glebas. O curioso é que a constrangedora pobreza arquitetónica das unidades produzidas pelo Estado, que pipocaram em periferias de todo o país, não parecia causar muito incómodo a profissionais muito mais ocupados em lutar politicamente pela realização dos conjuntos, de preferência com a participação dos futuros moradores organizados em associações. "Os anos 1960 foram os anos dourados da utopia arquitetónica", lembra a professora Suzana Pasternak Taschner. "Ensinava-se nas escolas de arquitectura que a manipulação do espaço conduziria à manipulação social; opor-se ao governo parecia ser mais importante do que adquirir formação profissional, e os trabalhos escolares acabavam sendo avaliados a partir das posições políticas defendidas pelos autores." Era também a época áurea do Planejamento Urbano, com todos os seus planos mirabolantes, onde se tinha certeza de que, através da simples acção profissional, estaria assegurada uma distribuição regional mais equilibrada. Hoje se sabe que o período era de um estranho optimismo oficial, imposto, que vinha no mesmo pacote do propagandeado Milagre Económico Brasileiro e da conquista do título de tricampeão mundial de futebol, em 1970, para ficar em apenas dois grandes alardes internacionais. Neste contexto, a questão da moradia dos mais pobres ganhou tanta importância dentro do campo de actuação profissional do arquitecto da época, que a própria palavra Habitação, constante no Novo Dicionário da Língua Portuguesa como "lugar ou casa onde se habita; morada; vivenda; residência" (Holanda Ferreira: 712), passou a designar, entre políticos e colegas de profissão, exclusivamente aquela destinada a abrigar população de baixa renda. A importância do tema é completamente justificada; a redução de significado do termo que o designa, não.

Em um contexto desses, onde o universo reduzido e tenso da pesquisa sobre o assunto Habitação era dominado por apenas dois grandes temas - as políticas de sua viabilização, visando a organização popular, e a busca de soluções técnicas, visando o barateamento do produto final -, é fácil supor que preocupações com a qualidade espacial das unidades em função dos modos de vida de seus ocupantes só podiam ser vistas como, no máximo, veleidades burguesas.

\section{Everybody wants to live in cities}

É também por volta das décadas de 1950 e 1960 que a informatização começa a dar sinais de um desenvolvimento capaz de permitir-lhe suceder à mecanização. Apenas trinta anos mais tarde, a 


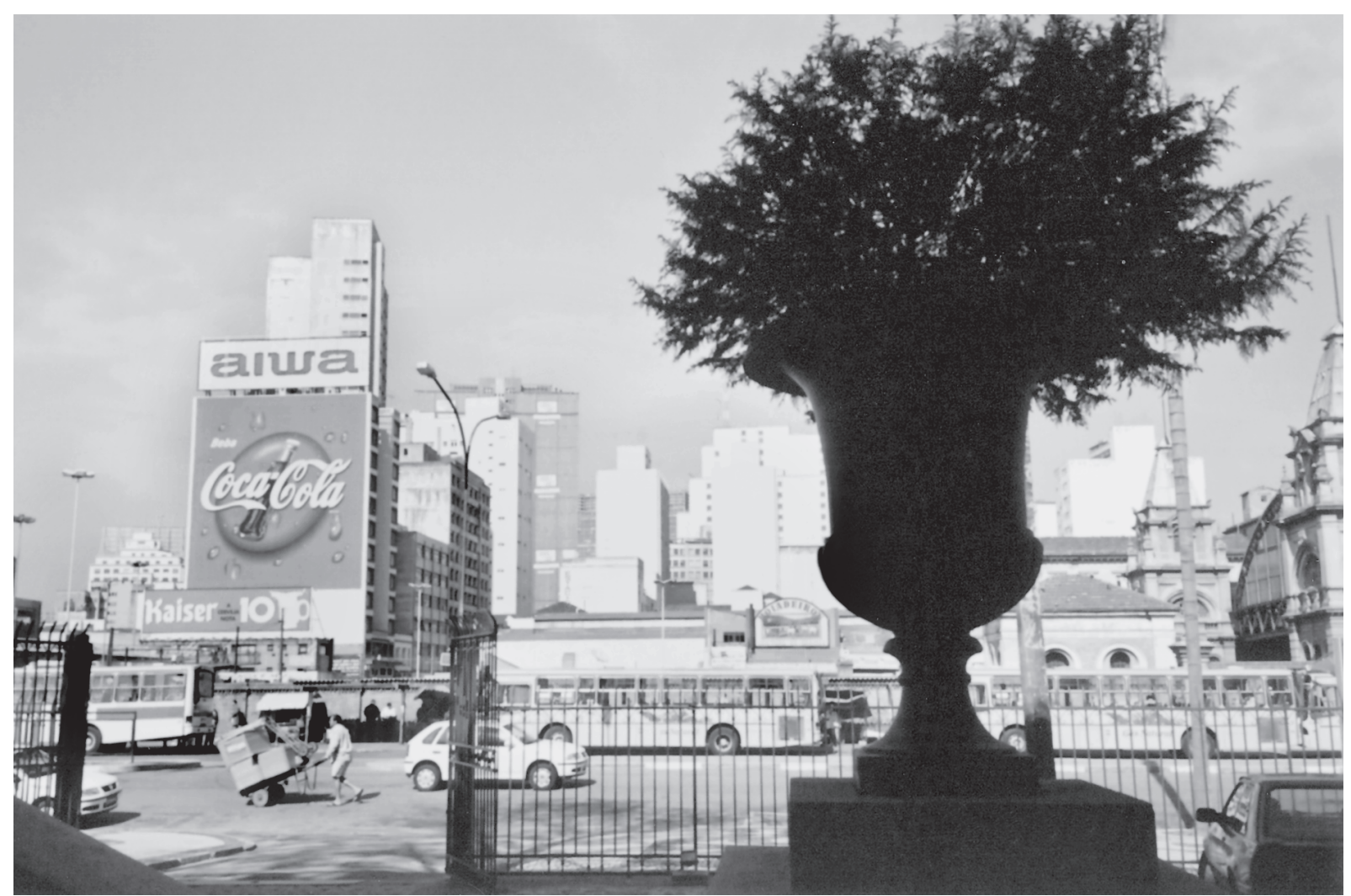

São Paulo, 2002 / Foto de Marcelo Feijó.

comunicação à distância já se encontra completamente modificada, as noções de deslocamento postas em cheque, enriquecidas com a banalização do conceito de realidade virtual. Diferentemente da sociedade industrial, na qual a população agrupa-se em pólos onde está a informação, na emergente sociedade pós-industrial, como tem sido chamada, a informação é que seria levada aos indivíduos, e o lugar onde eles efectivamente se encontram importa pouco. Os modos de vida metropolitanos propagam-se também através dos meios de telecomunicação, o que contribui, sem dúvida, para o movimento de população, em curso, a partir das grandes cidades do mundo em direcção a comunidades menores. Como tantas outras metrópoles do mundo, São Paulo tem experimentado o chamado efeito doughnut, que significa o decréscimo de densidade populacional nas áreas centrais e o aumento de população além de suas fronteiras administrativas. Essa migração tem, no entanto, limites claros. Ela se apoia nas novas possibilidades de comunicação à distância, que permitem que, mesmo em se morando em periferias, esteja-se em contacto constante com os eventos, serviços e instituições situados no núcleo central. Desse modo, as preferências acabam recaindo sobre cidades menores, mas situadas nas franjas da aglomeração principal, a uma distância do núcleo central facilmente percorrível em automóvel ou em transporte colectivo.

\section{Mais Clientes, mas com Menores Bolsos}

Por um lado, é verdade, assistiu-se, nas últimas décadas, a um empobrecimento generalizado da população após tantas crises e planos económicos. Por outro, percebe-se um real e constante aumento do número de consumidores que não possuem as mesmas fortunas da elite de antão, mas que dispõem-se a empenhar-se financeiramente para obter a tão sonhada casa própria, abrindo, para isso, magras carteiras. O mercado imobiliário, tanto o de unidades particulares quanto o de unidades públicas, reagiu oferecendo casas e apartamentos cada vez menores e desprovidos de equipamentos, na esperança de chegar a um produto pelo qual o consumidor-alvo 
pudesse pagar. Basta ler matérias especializadas e anúncios nos jornais do período para dar-se conta destas mudanças. Os bairros das grandes cidades foram inundados por lançamentos de apartamentos pequenos que insistiam em abrigar famílias nucleares inteiras em áreas cada vez menores. O quarto de empregada desapareceu, ou, em casos menos extremos, passou a constituir uma terceira e minúscula opção de dormitório, dando origem a uma tipologia hesitante, na qual possuía duas portas: uma para o corredor dos quartos, outra para a área de serviço. Podia-se bloquear uma ou outra porta e, com isso, supostamente, alterar a função e o status do cômodo, apesar de suas dimensões não pararem de diminuir. A tipologia do 'terceiro opcional', como ficou conhecida, começava a garantir, no mercado imobiliário, o lugar de destaque absoluto que ocuparia ao longo de toda a década de 1980, em apartamentos para todos os bolsos. Por sua vez, a cozinha foi ficando cada vez mais rectangular e menor, limitando-se, via de regra, a uma parede equipada e uma passagem permitindo acessá-la: um novo corredor, ligando o hall de entrada à área de serviço. Ganhou, no entanto, tomadas suplementares, em vista da invasão dos novos electrodomésticos. A sala de estar, no singular ou no plural, foi o único cômodo que teve sua área francamente aumentada, às vezes prolongada pelo acréscimo de varanda, em uma tendência que se verificou em apartamentos de qualquer área e preço. Os banheiros diminuíram mas permanecem em número de, pelo menos, três: um na suíte do casal, outro destinado aos filhos, o terceiro, à empregada. Como se vê, a atenção à família nuclear ainda é clara.

A redução de áreas do espaço doméstico é um fenómeno relativamente recente. Com todos os esforços pós-Segunda Guerra Mundial, o que se viu, nos países que receberam ajuda norte-americana para sua reconstrução, foi um ligeiro aumento das habitações menores e a acentuada diminuição das maiores. $\mathrm{O}$ Brasil não foge muito à regra. Em geral, todos os imóveis têm diminuído de tamanho, mas os apartamentos maiores tem se reduzido mais, segundo dados do SECOVI-SP. Em 1981, um apartamento de luxo com mais de três dormitórios tinha em torno de $509 \mathrm{~m}^{2}$. Quinze anos mais tarde, o mesmo programa cabia em $407 \mathrm{~m}^{2}$, com uma perda de $20 \%$ da área anterior. No caso do de três dormitórios, as reduções foram ainda maiores, da ordem de 25\%. Os apartamentos menores encolheram menos: o de dois dormitórios perdeu apenas $11 \%$ da área, e os de um quarto ou kitchennetes ficaram $17 \%$ menores. Muitos dos apartamentos de um ou dois quartos, outrora reservados às carteiras menos recheadas, viram sua área aumentar por deverem abrigar, com frequência cada vez maior, singles, casais sem filhos ou com um único filho, de poder aquisitivo alto, que preferem não ter muito trabalho com a casa mas que querem, por exemplo, poder receber amigos em salas amplas. Em muitos destes casos, a sala e a cozinha fundiram-se em um único cômodo, um pouco maior do que as antigas salas de estar, o que terminou por influenciar os hábitos culinários dos moradores, desencorajando-os, por exemplo, a prepararem frituras e pratos de longo cozimento. Descongelar algo no microondas seria mais adequado? O mercado também estava atento, oferecendo os equipamentos necessários.

O fato é que, rica ou menos rica, a imensa maioria da população das grandes cidades brasileiras tem se visto confinada em casas e apartamentos cada vez menores, cuja estanqueidade funcional dos cômodos conflita-se com a crescente demanda por privacidade dos membros do grupo doméstico. Quartos de dormir cada vez menores abrigam mais e mais equipamentos e itens de mobiliário - camas, mesinhas, beliches, armários, mesas de trabalho, racks e estantes, além de televisores, aparelhos de som, telefones, eventualmente computadores, talvez conectados à internet -, lista mais ou menos longa segundo o poder aquisitivo e o número dos moradores, confirmando a tendência a uma sobreposição não planejada de funções no espaço doméstico. $\mathrm{O}$ fato é que actividades antes estranhas ao programa doméstico, como o trabalho remunerado, ajudado ou não por equipamentos de transmissão de informação à distância, têm forçado sua entrada em uma estrutura espacial antiga, concebida para um modo de vida que se baseava na assimetria de papéis do modelo familiar nuclear, no qual o pai provedor buscava fora de casa o sustento material da família, enquanto a mãe encarregava-se do gerenciamento da esfera privada. Da mesma forma, algumas actividades antes claramente domésticas têm tendido a deslocar-se para o exterior da habitação, incluindo, muitas vezes, as refeições. É clara a dificuldade de se apropriar de espaços cada vez mais reduzidos utilizando-se mobiliário e equipamentos convencionais, que excluem, 
portanto, na grande maioria dos casos, a sobreposição ou alternância de funções, provendo suporte apenas às actividades constantes do programa habitacional convencional. Mesmo nos casos em que o projeto arquitectónico prevê dispositivos visando uma possibilidade contínua de reorganização espacial, como divisórias móveis ou removíveis, ou instâncias multi-uso, o fato é que, ao inserir nesses espaços peças de mobiliário convencional, e, portanto, em geral, monofuncionais, o uso do cômodo é fixado, dificultando bastante ou mesmo excluindo-se a possibilidade de realização de novas actividades.

\section{Edifícios, Condomínios, Conjuntos, Flats: ilhas no mar urbano}

Para compensar estas perdas de área das unidades, começaram a surgir, inicialmente nos edifícios de alto luxo, equipamentos de uso colectivo como play-grounds e piscinas para crianças, seguidos de quadras de esporte e de piscinas maiores, para adultos. O que passou a fazer, segundo os corretores de imóveis, com que a balança pendesse para o lado destes edifícios-com-ares-de-clube quando a dúvida confrontava o comprador a apartamentos com acomodações e dimensões semelhantes, o que não era difícil, dada a uniformidade das plantas. Duas razões importantes parecem estar por trás destas escolhas, como apontam desdobramentos das décadas seguintes. Uma, a extrema preocupação com o próprio corpo, subproduto do individualismo que se acentuava à medida em que o grupo familiar perdia importância social. No entender dos incorporadores de imóveis dos anos 1970, os cuidados que os moradores destes edifícios gostariam de ter com o corpo estavam associados ao lazer, notadamente ao lazer colectivo. Cuidados individuais, como o proporcionado por longos banhos de banheira, andavam em desuso. Banidas dos cômodos de higiene por restrições económicas e de área, as banheiras terão de esperar a segunda metade da década para, vestidas com a nova e sedutora roupagem dos primeiros jacuzzi, fazerem sua volta triunfal ao espaço doméstico de alto luxo, ainda que confinadas dentro da suíte do casal. Aliás: dentro da suíte da dona da casa, que verá também seu closet ser separado do closet de seu marido. Uma tendência de supervalorização da esfera colectiva do edifício já estava em curso. Além de tudo, piscinas e quadras não custavam muito caro e davam status aos moradores. A outra razão para estes serviços foi, com certeza, a chamada escalada da violência, agravada, por sua vez, pelo empobrecimento da população. Ao invés de ir para o trabalho deixando os filhos pequenos serem levados para uma pracinha da vizinhança pelas mãos de uma babá que é, no fundo, uma desconhecida, os pais mais ricos passaram a preferir que a pracinha viesse fazer parte dos domínios protegidos do edifício. Foi o que bastou para que tais empreendimentos se armassem não só de espaços para crianças, mas também de grades, muros, guaritas, câmeras, agentes de seguranças, em uma espiral que não parou mais de subir. Boa parte destes atributos de distinção, típicos dos condôminos abastados dos anos 1970, disseminaram-se com rapidez nos anos seguintes, estendendo-se à população de menor renda. As piscinas desta última eram, talvez, um pouco menores, a área do play-ground também, mas a maioria dos condomínios verticais chegará ao final da década de 1980 com pelo menos alguns dos serviços que, inclusive, lhes serviriam de passaporte para a comercialização em um patamar mais vantajoso. Hoje, os novos lançamentos de prédios de apartamentos médios em São Paulo costumam ter também saunas, ducha e a indefectível sala de musculação, cujos aparelhos ajudam a sugerir a profundidade do bolso dos condôminos. Para diferenciar-se, os conceptores de edifícios de alto luxo estão tendo que suar a camisa. Não bastou acrescentar uma sala de massagem e outra de repouso às saunas, criar um salão de festas adultas separado do das infantis, equipar com um deck de madeira as piscinas, agora semi-olímpicas e aquecidas: hoje, muitos destes imóveis contam também com um salão de jogos para crianças e outro para adultos, uma confortável sala com home theater, churrasqueiras e fornos de pizza, às vezes na varanda de cada apartamento, conexões para automação residencial, quiosques para massagem oriental em meio a jardins especialmente desenhados, e já se fala em equipar as áreas de jogos infantis com micro-computadores e reunir, em um andar, escritórios recheados com recursos informatizados para uso dos moradores que preferem sair de casa para trabalhar sem ter de pegar trânsito. Esta última é uma das poucas propostas que não visam incrementar o lazer, mas 
o trabalho. Não deixa de ser interessante como busca de relocação de certas actividades produtivas, situadas, neste caso, em uma inovadora posição entre os domínios privado e público. Mas não altera o fato de que todos estes serviços e apostos ajudam a tornar bem mais nítidas as fronteiras entre estes dois domínios.

Usando as mesmas tintas e os mesmos pincéis, pode-se também retractar os condomínios horizontais fechados, cuja construção na cidade ganha expressão a partir do final da década de $1970^{10}$. São, antes de tudo, porções de tecido urbano, supostamente melhor protegidas contra a violência da cidade porque esta protecção não depende das escassas disponibilidades do Poder Público. São ilhas dentro da metrópole, cujo projecto, na maioria dos casos, perde a oportunidade de estabelecer relações privilegiadas de vizinhança em seu interior, como as antigas vilas, ou mesmo de propor novas concepções de arruamento e de implantação. Condomínios horizontais, formados de casas isoladas, tiveram seu desenvolvimento limitado por factores óbvios, tipicamente metropolitanos, como o preço sempre ascendente do solo e a crescente dificuldade em se encontrar áreas disponíveis. Acabaram indo espalhar-se nas terras dos municípios vizinhos a São Paulo, o que se tornou uma verdadeira coqueluche para a classe média alta durante as décadas seguintes. Tanto que muitas ruas e bairros de São Paulo e de outras grandes cidades brasileiras já foram fechados, desde então, por iniciativa dos próprios moradores, que passam a dividir os custos da segurança particular, da limpeza e do jardineiro, num dificilmente reversível processo de privatização do espaço público. O melhor exemplo, o mais clássico, é, sem dúvida o de Alphaville, na Grande São Paulo, com sua escala impressionante. Criado nos anos 1970, a vinte e cinco quilómetros de São Paulo, o conjunto deveria reunir as vantagens da cidade às do campo, evitando seus inconvenientes. Antigo ideal. Cúmulo do refinamento, o nome do lugar: Alphaville, como o filme de Godard ${ }^{11}$. Alphaville é um paraíso para, pelo menos, dois profissionais: o incorporador, que lucra com o medo da população rica, e o agente particular de segurança, que encontra-se aí em seu reino encantado. Patrulhas percorrem permanentemente as alamedas floridas, câmeras vigiam noite e dia os principais locais, enquanto guardas postados na única entrada - funil causador de enormes engarrafamentos ao fim do dia - controlam a identidade de moradores e de visitantes, esses últimos sempre encarados como intrusos indesejados, até prova em contrário. Sua população aproxima-se hoje de trinta mil pessoas, ocupando sete mil residências, entre casas e apartamentos, nem todos muito contentes com a vida que levam no bairro, aliás. "Ao contrário do lugar ideal para viver que imaginavam, depararam-se com problemas de infra-estrutura, de trânsito, ambientais e de convivência muito semelhantes aos da cidade", constata Auro Moreno Romero, autor do estudo Alphaville: ilusão de paraíso. ${ }^{12} \mathrm{O}$ grande problema que a fórmula coloca é, sem dúvida, o seu aspecto de cidadela, de gueto de pessoas ricas que desconhece a diferenciação social, divorciando-se da vida urbana no que ela tem de melhor: sua diversidade, que, em princípio, conduz à aceitação e à tolerância. A lógica do mercado, no entanto, não parece preocupar-se com estes aspectos sociológicos, e tende a limitar mais ainda a diversidade de perfis dentro dos conjuntos.

Em geral, as disposições relativas à segurança dos condomínios também sofisticaram-se inacreditavelmente, estimuladas pela informatização sensores de guarda electrónica, patrulhas 24-horas, câmeras de televisão em circuito fechado em todas as áreas comuns, identificação na portaria por cartão magnético ou por leitura da íris, por exemplo. Seduções publicitárias à parte, seria bom que os futuros moradores pesassem seriamente os prós e contras desta escolha. Como se isso fosse possível. A verdade é que todos estes desenvolvimentos, desde o predinho de apartamentos de sala-e-quarto, com uma pequena piscina e uma gangorra no térreo, até o luxuoso condomínio de vários edifícios espaçosos com seus clubes e vastos gramados, tem em comum o fato de reforçarem a ideia, cara aos corretores de imóveis, de que o espaço doméstico deve assemelhar-se a uma promessa de felicidade, de repouso, de divertimento

\footnotetext{
${ }^{10}$ Alphaville, em Barueri, foi o primeiro de todos os loteamentos horizontais fechados, dentro do qual proliferaram os primeiros condomínios paulistanos. Sua implantação iniciou-se no final dos anos 1970.

11 No filme, de 1965, Alphaville é o nome de uma cidade futurista situada em um planeta distante.

12 Citado por Zakabi (1998).
} 
permanente e, se possível, de refinamento, opondo-se a um espaço público estressante, caótico, perigoso e pobre. Ou, relembrando Hollywood, a ideia de que a casa contém o antídoto a qualquer mal que o exterior possa causar ao homem. "There is no place like home", já cantava a pequena Dorothy, de 'O Mágico de Oz'. Algo assim como o que se pensava também na Paris do começo do século XIX, quando os páteos dos festivos hôtels particuliers começaram a ganhar muros altos $\mathrm{e}$ portões espessos, e suas janelas, vitrais e pesadas cortinas.

No outro prato da balança situam-se os pobres conjuntos de habitação social, construídos no país todo ao longo das últimas décadas, para ficar apenas nas realizações recentes. Seria redundante requentar discussões, até certo ponto já bastante esgotadas, sobre a falta de qualidade espacial destes pedaços de cidade produzidos na marra, seja no que se refere às suas esferas pública e colectiva, seja no que concerne o espaço privado das unidades. Vale a pena, no entanto, deter-se, ainda que rapidamente, diante do que foi, recentemente, a única tentativa legítima de revisão do projecto habitacional de interesse social em São Paulo: as moradias construídas pela Prefeitura da cidade entre os anos de 1989 e 1992. Por que legítima? Primeiro, porque dispôs-se a repensar praticamente todas as etapas da produção das habitações, começando pela escolha do terreno, recusando os padrões que até então vinham vigorando com as bênçãos de construtores, proprietários de terra e poder público. Segundo, porque mostrou vontade política para implementar mudanças, e sabe-se através de realizações em várias partes do mundo, em diferentes momentos históricos, que, nestas questões, vontade política é mais importante do que vultosos recursos financeiros. E terceiro, porque quase cinquenta e cinco mil unidades foram produzidas, sem o aposto vulnerabilizante das 'experiências-piloto', mostrando que não é impossível inovar neste terreno quando se está verdadeiramente disposto a fazê-lo, e por um custo equivalente ao custo da moradia convencional. Um dos grandes méritos da iniciativa foi o de trazer o arquitecto de volta ao cenário da produção da habitação social, cuja saída parecia, aliás, absolutamente inexplicável: na construção convencional, muitos projectos tem sido desenvolvidos até pelas próprias construtoras, submetendo a qualidade espacial a critérios meramente produtivos e económicos. Outro bom filho que à produção da casa torna é o próprio morador, chamado pelo programa tanto para decidir sobre soluções espaciais quanto para participar da construção em mutirão, em certos casos. Estes inegáveis méritos constituem, ao mesmo tempo, fragilidades óbvias. Convidado a opinar na organização de sua futura casa, e sem outra referência além da casa convencional - tanto a de ricos como a de menos ricos -, é natural que o futuro usuário limite-se a propor mecanismos espaciais capazes, a seu ver, de resultar em espaços que, mesmo de maneira tímida, aproximem-se dos seus modelos. É, sim, natural, porque quem deveria debruçar-se sobre a questão das relações entre o espaço doméstico e o modo de vida de seus usuários é o profissional arquitecto, que, pelo menos em tese, dispõe de dados estatísticos sobre a população-alvo, tem em mente os desenvolvimentos históricos destes modelos, consegue relativizar a importância atribuída pelos futuros moradores a certas reivindicações, e separar o joio de falsos imperativos do marketing imobiliário do trigo de certas necessidades emergentes que a população ainda nem saberia formular com clareza. Nestes projectos feitos para a Prefeitura de São Paulo no começo da década, arquitectos, políticos e moradores priorizaram a revisão do espaço público, introduzindo, em alguns casos, a riqueza da esfera colectiva. É coerente, dentro dos objectivos maiores da administração da época, que visavam a contribuir para o desenvolvimento, no povo, de uma consciência de cidadania que teria nas áreas comuns do próprio bairro o cenário mais imediato para suas primeiras manifestações. Nada, no entanto, teria impedido que esta discussão se estendesse ao interior das unidades, sobretudo no que se refere a assuntos como o trabalho a domicílio, bastante comum nesta parcela da população, às crescentes reivindicações por autonomia e privacidade dos membros do grupo doméstico, ou mesmo à própria diversidade dos formatos familiares, já que a imensa maioria das unidades destina-se apenas a famílias nucleares. Se certos dispositivos, como a previsão de ampliação de algumas unidades, amplos terraços em outras, ou um cuidado generalizado e bem-vindo com a expressão plástica dos conjuntos, são dignos de nota, prevalece, no geral, uma organização interna do espaço doméstico cujas soluções recorrentes são velhas conhecidas. 


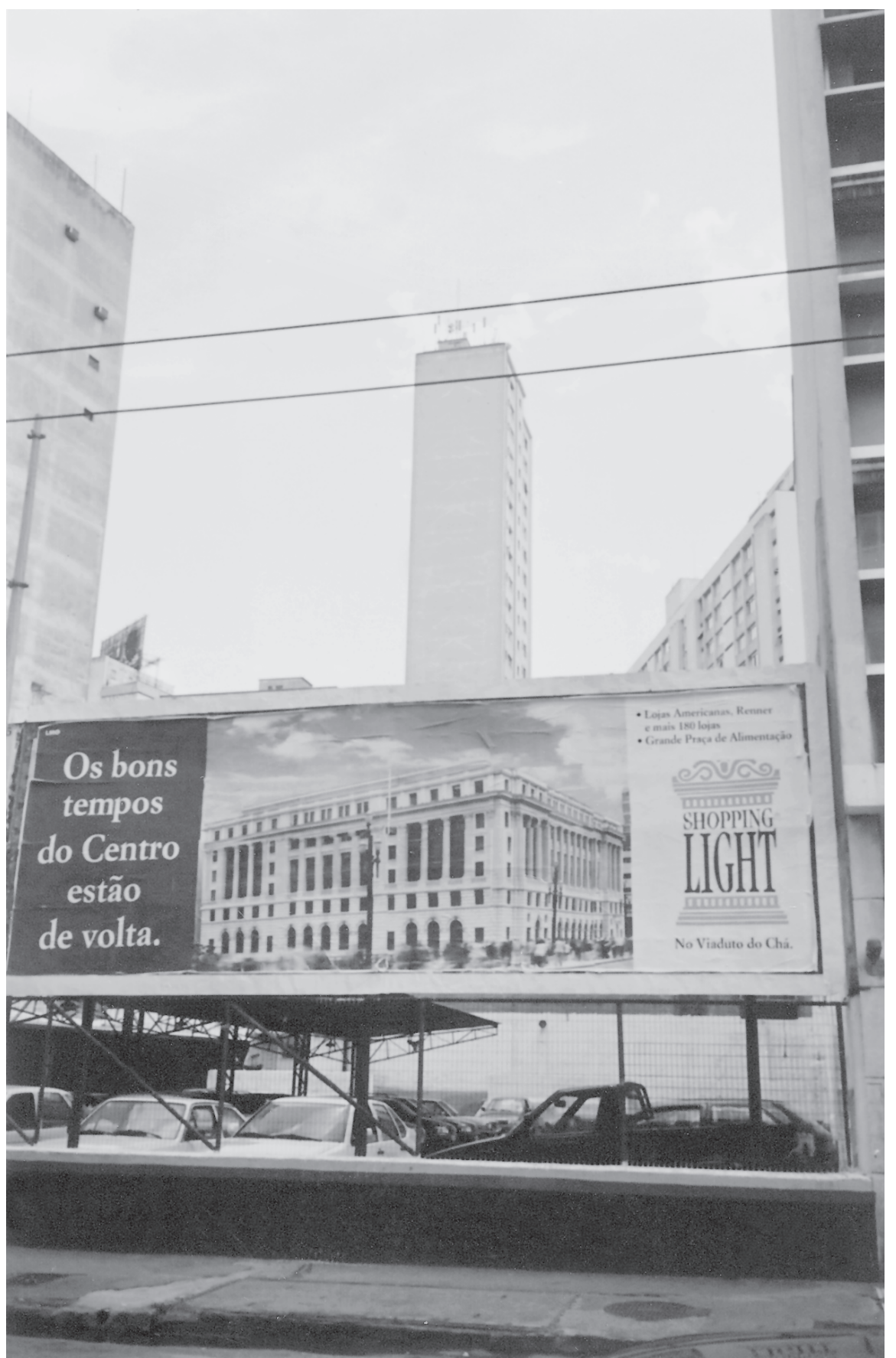

Foto de Marcelo Feijó / São Paulo.

No entanto, novas fórmulas de habitação têm-se delineado por iniciativa do mercado imobiliário que, juntamente com os profissionais de marketing, está atento às transformações em curso do perfil dos usuários. Flats, apart-hotéis, residenciais com serviços, residências de conveniência, vários nomes para a fórmula norte-americana que encantou Le Corbusier, na primeira metade do século Xx, e que, para retomar a definição de Elizabeth Cromley (1991:22), reúne “um híbrido de duas idéias: a privacidade de uma unidade de moradia unifamiliar e os elaborados serviços de arrumação e de preparação de refeições oferecidos em hotéis." O curioso é que o conceito novaiorquino de apartment-hotel, surgido na década de 1870 , tenha tido desdobramentos tão distintos, e, em fim de contas, parecidos, como as Unités d'Habitation corbuseanas e os flats e apart-hotéis paulistanos. $\mathrm{Na}$ França, a tradição fourierista e de inovação no campo da habitação social conduziu a soluções 
habitacionais para os mais pobres, financiadas pelo governo. No Brasil, a centenária exclusão das classes pobres de qualquer iniciativa que visasse a melhoria de qualidade da moradia, associada a uma especulação imobiliária às vezes até incentivada pelo governo, deu origem a uma habitação para os mais ricos. Em 1975, surgiu o primeiro edifício de flats de São Paulo, trombeteado por campanhas publicitárias que desafiavam o público a conhecer o 'jeito moderno de morar’ e vendiam o apart-hotel como a 'casa do futuro'. Hoje, são muitas as pessoas que tem sua moradia permanente nestes edifícios, mas a maioria das unidades acaba servindo mesmo a pessoas de passagem. Entre hóspedes e moradores permanentes há de tudo, desde executivos de passagem até idosos solitários, casais jovens sem filhos, solteiros começando a vida, descasados recomeçando, e, por que não?, famílias formadas por pai, mãe e filhos. Os serviços típicos de hotel já são um alívio para quem não quer, ou não tem tempo para dedicar-se a tarefas domésticas. Mas, como se trata de um edifício residencial com serviços, estes últimos tem conhecido um grau crescente de especialização. Os serviços tem sido continuamente revistos: o espaço, não. Ainda assim: para idosos, por exemplo, há prédios com enfermeiros de plantão para emergências, além de restaurante e de facilidades para pessoas com mobilidade reduzida, salas de jogos com actividades programadas, viveiros de plantas e amplos jardins. Os edifícios para solteiros, que passaram também a ser a moradia clássica e temporária dos recém-descasados, possui salas mais amplas do que normalmente, para pessoas que parecem especialmente gostar de receber amigos. Já um edifício prioritariamente para fanáticos da boa forma física tem, em suas áreas comuns, quadras de tênis, de squash, pistas de cooper e de skate, além das habituais salas para ginástica, jogos, saunas e duchas. Mas as novidades mesmo ficam por conta de lançamentos bem recentes, que aproximam o mundo do trabalho do espaço residencial. Um deles propõe prédios vizinhos em um mesmo terreno, o primeiro abrigando apartamentos, o outro escritórios, um terceiro, cinemas, lojas e restaurantes. Com isso cria-se um pequeno núcleo de suficiência para o executivo em viagem de trabalho, mas que se estende ao eventual morador permanente. O trânsito difícil e o medo gerado pela insegurança desaparecem do caminho entre casa, trabalho e lazer, é verdade. A solução, no entanto, prega uma artificialidade flagrante, por apoiar-se, justamente, em uma clara tentativa de anulação dos efeitos próprios à vivência urbana, com seus parques, suas velhas ruas, seus bairros feios que suscitam reflexões sobre o verdadeiro papel dos diferentes actores no cenário social, etc. Tanto quanto condomínios fechados, clubes, shopping centers, e quaisquer empreendimentos que reúnam pelo menos duas destas fórmulas, morar neste conjunto de prédios é morar em uma bolha asseptizada.

Para a população de baixa renda há uma 'experiência' em curso, como gostam de chamá-la os técnicos da Prefeitura da cidade: cinco unidades no conjunto Cingapura da Água Branca, todas térreas e com algumas facilidades como alças no banheiro e portas mais largas, povoam o triste e breve relato sobre o que se fez, nas últimas décadas, no sentido de se repensar a habitação social em função das novas necessidades de seus ocupantes. Comparadas ao que a iniciativa privada tem feito para os ricos, que já não é muito, as unidades da Água Branca não significam nada, além de evidenciar a centenária despreocupação que o poder público brasileiro demonstra em relação à qualidade espacial da habitação dos mais pobres, com raríssimas e honrosas excepções. Também reafirmam o expediente da 'experiência piloto" como mecanismo usado para fazer crer à população que o governo sabe muito bem o que deve ser feito e que está, com tais experimentos, preparando-se séria e sabiamente para fazê-lo. Em um futuro que só Deus sabe quando será.

\section{O Teletrabalho e as Delícias do Homeshopping}

Trabalhar em casa é um hábito antigo. Desde tempos medievais, quando as noções de espaço público e privado ainda estavam por serem cunhadas, trabalho e vida doméstica confundiam-se em um mesmo espaço, envolvendo um grupo doméstico igualmente formado por parentes e não-parentes do dono da casa. O século XVIII europeu presenciou o nascimento da indústria, ao mesmo tempo em que certos segmentos como a fiação, a tecelagem, a confecção ou a relojoaria delegaram ao trabalho realizado em casa certas actividades de apoio à produção em usina. $\mathrm{O}$ trabalhador 
situava-se, neste caso, bem próximo ao artesão, uma vez que organizava e realizava suas tarefas de maneira autónoma.

O teletrabalho, tal qual tem sido entendida hoje esta expressão, é produto da aplicação das telecomunicações e da informática às actividades remuneradas, permitindo comunicar-se à distância, intercambiando-se informações e dados. A partir daí, o teletrabalho deixa de equivaler à actividade profissional simplesmente realizada em casa, constituindo uma ruptura da tradicional organização do trabalho. Seus defensores proclamam as delícias de poderem desenvolver suas actividades profissionais sem sair de casa, permanecendo ao lado da família, quando têm uma, economizando o dinheiro da gasolina ou do transporte colectivo, trabalhando segundo seu próprio ritmo, sem ter de estar o tempo todo em contacto com uma hierarquia funcional. Haveria, ainda, vantagens óbvias para a colectividade: se o deslocamento físico é substituído pelo virtual, o trânsito de automóveis teria consequências menos incómodas. Corolário igualmente evidente, os congestionamentos muitas vezes acabam transferindo-se para a rede telefónica. Seus opositores, no entanto, representantes sindicais em sua maioria, garantem que há mais ameaças do que boas promessas nesta nova forma produtiva. Apontam o isolamento físico e social como causa principal da solidão expressa por grande parte dos teletrabalhadores consultados em diferentes enquetes. Além disso, a proximidade com a família seria, antes, um problema, como declaram diversos entrevistados que se queixam da ausência de limites claros entre vida familiar e vida profissional. Alguns sentem que o espaço profissional invade o doméstico, e acabam trabalhando muitas horas mais do que trabalhariam no escritório da empresa.

Tanto o indivíduo que, assalariado de uma empresa, passa a trabalhar em casa conectado à central por meio de equipamentos - telefónicos, informatizados e suas combinações -, quanto aquele trabalhador autónomo ou pequeno empresário que transfere suas actividades profissionais para seu espaço doméstico, ambos parecem ainda um pouco perplexos com os inesperados efeitos deste casamento tecnológico entre territórios público e privado. Nestes como em outros casos, tem-se assistido a uma supervalorização do espaço doméstico, ainda que não claramente expressa. Além de actividades de trabalho remunerado, é preciso ainda lembrar a tendência de que operações como consultas bancárias, encomendas de mercadorias e visualização de filmes e notícias estejam sendo cada vez mais efectuadas a partir do espaço doméstico, e que algum efeito em seu carácter de espaço privado estas transformações provavelmente terão. Ao mesmo tempo, quando pertencentes aos estratos de renda médios da população, muitos teletrabalhadores domésticos das grandes cidades parecem preferir cada vez mais almoçar fora de casa, numa curiosa e pouco estudada inversão de cenários das actividades relacionadas à tradicional oposição entre casa e trabalho. Essa condição certamente contribui para embaralhar os limites e a própria compreensão dos elementos constituintes das esferas pública e privada, e, por consequência, das faces pública e privada de seus usuários.

No que se refere à relação entre os membros do grupo doméstico e a mediação das tecnologias de informação e comunicação, a escolha entre convívio ou isolamento passa a levar em conta a banalização da televisão na grande maioria dos domicílios, a posse de micro-computadores conectados à Internet, com preço e condições de pagamento cada vez mais acessíveis a parcelas mais amplas da população, e as maiores possibilidades de obtenção de uma linha telefónica, facilitada pelas recentes alterações de regras do sector. Nas classes médias, o telefone celular parece afirmar-se como instrumento de controle dos pais sobre os filhos, permitindo o monitoramento de suas actividades sem a ajuda de pessoal doméstico. Aliás, o próprio pessoal doméstico tem seu trabalho supervisionado à distância pelos patrões, via internet, através de sistemas de monitoramento com imagens geradas por micro-câmeras que permitem também fiscalizar atividades dos filhos na escola. Auxiliada pelas mídias e carente de maior reflexão, a encenação panóptica vai se tornando comum na vida das pessoas, de forma nunca antes vista (Tramontano, 2003).

\section{Habitação Contemporânea, o Impasse}

No que concerne o desenho do espaço doméstico para esta população em transformação, o ritmo das inovações tem sido bem mais lento. Os paulistanos habitam casas e apartamentos cujos espaços tendem a assemelhar-se a tipologias que 
vão, como se viu, do modelo da habitação burguesa europeia do século XIX, caracterizado pela trilogia de áreas social, íntima e de serviços, ao arquétipo modernista da habitação-para-todos, com sua uniformidade de soluções em nome de uma suposta democratização das características gerais dos espaços. Mesmo que agora tendam a habitá-la grupos domésticos cujo perfil difere cada vez mais da família nuclear convencional, e cujos modos de vida apresentam uma diversidade cada vez maior, o desenho dos espaços desta habitação permanece intocado, sob a alegação de que se chegou a resultados projetuais economicamente viáveis, que atendem às principais necessidades de seus moradores.

É verdade que as principais tipologias habitacionais, encontráveis, por exemplo, nas periferias das grandes cidades do mundo inteiro, permanecem aproximadamente as mesmas há décadas. O Movimento Moderno europeu do entre-guerras constituiu o primeiro e único momento em toda a história da Arquitectura em que o desenho e a produção de espaços de morar foram integralmente revistos, analisados de acordo com critérios claramente formulados, cujos resultados nortearam - e ainda norteiam - boa parcela dos projectos de Habitação em todo o mundo ocidentalizado. Além disso, tais análises incluíram o projecto da habitação social entre as atribuições do arquitecto, o que, por si, já seria suficiente para assegurar-lhes destaque no cenário arquitectónico. No entanto, os arquitetos modernos previram uma habitação prototípica, que correspondia a um homem, a uma cidade, a uma paisagem igualmente prototípicos em sua formulação. Criaram um arquétipo, o da habitação-para-todos, ainda que a abrangência das proposições que ele continha tenha sido gradativamente desconsiderada pela lógica técnico-financeira dos empresários da construção, que preferiram apropriar-se apenas de elementos e conceituações economicamente rentáveis.

Nos anos 1960, um sopro de ar renovado pareceu reanimar o campo de investigações sobre a Habitação. Enfant terrible em uma Inglaterra conservadora, o grupo Archigram deu de beber às suas reflexões nas fontes das então novas tecnologias, da massificação através da imagem mediatizada, da constatação do individualismo crescente. Como os Modernos, os membros do Archigram tampouco dissociavam habitação e cidade. O tema da cápsula de habitação, tão caro ao grupo, traduzia-se em um espaço hipertecnológico e mínimo a serviço do indivíduo, e viu-se abordado em projectos que veiculavam conceitos como a cidade nômade ou a imagem como paisagem do movimento urbano. Ao abrigar apenas funções estritamente individuais e solitárias, a habitação, às vezes reduzida às dimensões de uma grande concha ou de uma mochila, pressupunha uma vida social dispersa através da cidade e do território. O espaço privado, produto do esforço de reconstrução do segundo pós-guerra europeu, parecia ser lido como um espaço transitório, provisório e quase secundário em relação a um espaço exterior supervalorizado.

Depois de Archigram, resta o silêncio no deserto de novas propostas em que se converteu o campo de pesquisas sobre habitação na maior parte do mundo. Social ou não, colectiva ou não, urbana ou não, projectada ou não por arquitectos, o fato é que seu desenho permanece aproximadamente o mesmo há muitas décadas, apenas com alguma variação de superfície e de equipamentos, em função, principalmente, de flutuações na economia dos diversos países. No que concerne a habitação colectiva, seja ela verticalizada ou horizontalizada, tanto os órgãos públicos produtores de conjuntos habitacionais como as construtoras e incorporadoras particulares têm se limitado a elaborar projectos urbanísticos ou a desenhar novas fachadas, adequando a novos terrenos, eventualmente a bolsos mais ou menos fartos, projetos de unidades já anteriormente utilizados. Mesmo quando o projeto é solicitado a escritórios de Arquitetura - o que, no caso da habitação social brasileira, por exemplo, é uma absoluta raridade -, seja por encomendas, seja por meio de concursos, as inovações das propostas limitam-se ao uso de alguma técnica construtiva alternativa ou a novos desenhos de fachada incorporando traços da moda, sem que, contudo, a função, o desenho e a articulação dos espaços de habitar sejam sequer questionados.

\section{Considerações Finais}

O habitante das grandes cidades do mundo parece assemelhar-se, cada vez mais, aos seus congéneres de outros países, agrupando-se em formatos familiares parecidos, vestindo roupas de 
desenho semelhante, divertindo-se das mesmas maneiras, degustando os mesmos pratos, equipando suas casas com os mesmos electrodomésticos, trabalhando em computadores pessoais que se utilizam dos mesmos programas, capazes de ler, em todo o mundo, as informações contidas em um mesmo disquete. Isto significa que, aparentemente impulsionada pela potencialização dos meios de comunicação de massa, uma enorme transformação de hábitos está em curso, minimizando, inclusive, a influência de culturas locais.

É sobretudo neste sentido que as transformações actualmente em curso são profundas: no ponto em que, equipado com meios mais performáticos de comunicação à distância, o local de trabalho tende a ocupar novamente o espaço da habitação, que deverá alojar um número mínimo

\section{Bibliografia}

ALGRANTI, L. M., 1997, Familias e vida doméstica. in MELLO E SOUZA, L. (org.) História da vida privada no Brasil. Cotidiano e vida privada na América portuguesa, São Paulo, Companhia das Letras.

BERQUÒ, E., 1989, "A família no século XXI: um enfoque demográfico", Revista Brasileira de Estudos de População. $\mathrm{n}^{0}$ 2. V. 6. Julho/Dezembro.

BERQUÒ, E. ,1998, Arranjos familiares no Brasil: uma visão demográfica, in NOVAIS, F. (org.) História da Vida Privada no Brasil. V. 4, São Paulo, Companhia das Letras.

BRUAND, Y.,1991, Arquitetura Contemporânea no Brasil, 2. ${ }^{\mathrm{a}}$ edição, São Paulo, Editora Perspectiva.

CASTELO BRANCO, H. ,1989, Família: indicadores sociais 1981-1987. V.1. Rio de Janeiro, IBGE.

CHARTIER, R. ,1991, A comunidade, o Estado e a família: trajetórias e tensões, in ARIÈS, Ph., Chartier, R. História da vida privada: da Renascença ao século das luzes, V. 3, São Paulo, Companhia das Letras.

CROMLEY, E., 1991, Apartments and collective life in nineteenth century-New York, in FRANCK, K., AHRENTZEN, S. (ed.) New households, new housing, New York, Van Nostrand Rheinhold.

IBGE, 1995, São Paulo 1994, São Paulo, IBGE.

Holanda Ferreira, A. B. (s. d.) Novo Dicionário da Língua Portuguesa, 1. ${ }^{\mathrm{a}}$ edição, 15. ${ }^{\mathrm{a}}$ impressão, Rio de Janeiro, Nova Fronteira.

LEMOS, C., 1985, Alvenaria Burguesa, São Paulo, Nobel.

PATARRA, N.,1988, "Rumo a um novo perfil demográfico", in São Paulo em Perspectiva, São Paulo: Outubro/Dezembro. de pessoas, talvez - e com, aparentemente, crescente probabilidade - uma única, criando o cenário que abrigará um novo tipo de força de trabalho, completamente fragmentada.

Sabemos que o processo de tomada de decisões, no que concerne o desenho da habitação, envolve uma infinidade de parâmetros de natureza política e económica, e não apenas reflexões específicas de projecto, assim como um grande grupo de profissionais, entre os quais o arquitecto. No entanto, acreditamos que a este profissional cabe estar atento às transformações cada vez mais intensas e profundas da sociedade cuja moradia ele é chamado a projectar. E que seus desenhos de novos espaços de morar serão fundamentais para influenciar os que detêm o poder de efectivar mudanças.

PROST, A.,1991, Fronteiras e espaços do privado, in História da Vida Privada: da Primeira Guerra aos nossos dias, V. 5. São Paulo: Companhia das Letras.

REIS FILHO, N. G. ,1994, Habitação Popular no Brasil 18801920, Cadernos de Pesquisa do LAP n ${ }^{\circ}$, São Paulo, FAUUSP.

REIS FILHO, N. G., 1970, Quadro da arquitetura no Brasil, São Paulo, Perspectiva.

SEADE, 2000, Mulher em dados 2000. São Paulo: Fundação Seade.

SEADE, 1994, Pesquisa de Condições de Vida. São Paulo: Fundação Seade.

TASCHNER, S. P., 1993, "Notas sobre a origem e a evolução das favelas paulistanas", in Sinopsis 19, São Paulo, FAUUSP.

TASCHNER, S. P. ,1995, São Paulo 90: em busca de local onde morar, in Anais do VI Encontro Nacional da ANPUR. Brasília: ANPUR.

TASCHNER, S. P. ,1998, Política habitacional no Brasil: retrospectiva e perspectivas. Cadernos do LAP n. ${ }^{\circ} 21$, São Paulo, FAUUSP.

TASCHNER, S. P. ,1997, Família, habitação e dinâmica populacional no Brasil atual: notas muito preliminares. In: GORDILHO-SOHZA, A. Habitar contemporâneo: novas questões no Brasil dos anos 90. Salvador: UFBa, pp. 243-254.

TRAMONTANO, M., 2003, Vozes distantes: organização e sociabilidade em comunidades informatizadas, in SILVEIRA, S. A., CASSINO, J. Software livre e inclusão digital, São Paulo, Conrad, pp. 113-133.

ZAKABI, R., 1998, "Condomínios informais" in Veja São Paulo, São Paulo, 20 de Maio, pp. 13. 